\title{
The Dialectical Relationship between Marx's Sinicization and Traditional Chinese Culture
}

\author{
Liu Guoping, Yang Xianzhi \\ Jiangxi College of Application Science and Technology, Nanchang, China
}

Keywords: Marx, sinicization, Chinese traditional culture

\begin{abstract}
After the Marx doctrine into Chinese, the collision of traditional culture and its first Chinese deep foundation, and then it Chinese combination of conditions, mutual promotion and common development, it is the Chinese people on the process of Marx's acceptance and transformation and the Marx doctrine of China process; Chinese traditional culture provides the foundation and supplement for the spread and development of Marx doctrine in China. The Sinicization of Marx doctrine is also the inheritance and development of the traditional Marx doctrine. The two complement each other and are inseparable.
\end{abstract}

\section{Introduction}

The introduction of the Marx doctrine is a major cultural event Chinese in modern history and political events, the fierce national struggle and national peril predicament, make introduction and dissemination of the Marx doctrine has become an urgent need for the situation. Marx's doctrine is the theory of proletarian liberation all over the world, which is produced in practice and directs the proletariat's revolutionary practice.

Traditional culture in China refers to a concept and power that the Chinese nation is unique to and dominate millions of people's actions. It's a pattern followed by people in daily life. The Sinicization of Marx doctrine is the combination of the basic principles of Marx and the characteristics and concrete realities of the Chinese age, so that it has Chinese characteristics and Chinese style. China's excellent traditional culture is an important source of the theoretical system of socialism with Chinese characteristics. The integration of the basic principles of Marx doctrine and the excellent traditional culture of China is an important path to smoothly push forward the historical process of Marx's Sinicization.

\section{Chinese traditional culture provides national form and cultural resources for the Sinicization of Marx doctrine}

The Sinicization of Marx has a profound Chinese national culture, which is the process of interweaving and blending of Marx doctrine and Chinese traditional culture. The essence of traditional culture has played a positive role in promoting the Sinicization of Marx doctrine.

\subsection{The social ideal of "Great Harmony" in China and the "communism" of Marx doctrine}

The understanding of social "Great Harmony" in Confucianism also reflects Marx's communist ideals to some extent and embodies the requirements of scientific socialism. In the "book of Rites" of the Confucian thought of "Great Harmony" is described as:" When the great way prevails, the world is equally shared by all. The talent and virtue are elected. Mutual confidence was emphasized and brotherhood was cultivated. Therefore, people regard all parents as their own, and treat all children as their own. The elders can live in happiness, the adults are employed by their talent, the youths can grow and educate. Widows and widowers, orphans, childless, ills and invalids are all well taken care of. Men and women all have an appropriate role in the society and family. Nature resources were fully used for the benefit of all, and not appropriated for selfish ends. People contribute their ability to society and not for the private gain. Thus evil scheming is repressed, and crimes fail to arise. So the doors do not have to be shut. This is called 'the Age of Great Harmony'.”. 
The Marx doctrine on the public ownership of means of production, the social wealth possessed by all citizens, everyone is trying to present a kind of labor, social harmony and stability of the situation, no looting, no war, people of mutual love such a social ideal of "Great Harmony" has many similarities. Mr. Sun Yat-sen also pointed out that socialism and communism were "Great Harmony" in ancient Chinese Confucianism. From pursuing the social form of "Great Harmony" to communism is the highest ideal of the Chinese people, it is also a reflection of the modernization of Chinese traditional culture, and also a unification of Marx's sinicization and traditional culture."

\section{2 "seeking truth from facts" in ancient China and Be realistic in everything one does in Marx's Theory}

Ban Gu's " os-Han Wang Xian Liu " first put forward the concept of "seeking truth from facts": "Wang Xian Liu..... repair the ancient learning, seek truth from facts" Here, Ban Gu praised Wang Xian Liu 's careful examination of ancient books on Pre-Qin philosophers, this is a rigorous and prudent way of learning that is "truthfully" and "keeping its original". The Tang Dynasty also has a comment on "seeking truth from facts": "Be sure of the facts, and to seek truth". It is pointed out that if we want to do knowledge, we should pay attention to grasping the factual basis so as to draw a true conclusion from the facts. In the late Qing Dynasty, the popularity of "real learning" prevailed. Scholars used the "seeking truth from facts" language and style of study to criticize the academic attitude of grandiose learning. It can be seen that the idea of "seeking truth from facts" in Chinese traditional culture has been coming for a long time, but it is confined to scholarly research. In the course of the introduction and development of modern Marx's doctrine, "seeking truth from facts" is no longer the only requirement of the study style and the attitude of learning, but it has become the guiding ideology of the construction of our party and state, and has become the mainstream ideology of Chinese society. Practice is the core concept of Marx's theory, and Marx doctrine holds that practice is the sole criterion for the origin of theory and the correctness of the test theory, which is in great agreement with the traditional Chinese culture.

\subsection{The Chinese traditional culture and the humanism of Marx's doctrine}

The so-called "people-oriented" is centered on human beings, focusing on people's life and value, putting people in the most important position. All activities and creation of human beings are meaningful only when they are doing for human beings. In China's traditional culture, there is a strong "people-oriented" idea. "People-oriented" was first made by the Guan Zhong, he said:" The beginning of the occupation of the tyrant is also based on the people. This rule is the consolidation of national chaos, national peril." Marx for the first time from the practical perspective, expounds the system of people in social history in the main position, the epoch-making establish "people-oriented" concept of history, is in the "outline of Feuerbach" (written in the spring of 1845) and Engels coauthored the "German Ideology" (written in the spring of 1846) first, really put people at the fundamental position, marking the full form of Marx's historical materialism "people-oriented". The construction of socialism with Chinese characteristics is not only the development of the Sinicization of Marx's doctrine, but also the inheritance of Chinese traditional culture.

\subsection{The integration of Marx doctrine and excellent elements in Chinese traditional culture}

There are essential differences between Marx doctrine and the problem of the times, the core content of the practice, the specific object of service, the values, the theoretical system and the function of the traditional Chinese culture. But we should also see that in addition to the essential differences between the two, there is a spiritual harmony, otherwise the Chinese can not really identify the western political trend of ideological trend in the European industrial society.

The humanistic consciousness in Chinese traditional culture is reflected in Confucianism. The Confucianist thought first distinguishes man's world from the world of things, regards man as the center of the universe and the highest stage of the development of organic matter. The existence of human beings has the special status that other objects can not compare and replace. The truth of heaven and earth are only meaningful to humanity only through humanitarianism. 
Marx's doctrine also has a strong sense of humanism. Marx and Engels lived in the era of European industrial civilization and the rise of the working class uprising. The problems that Marx and Engels had to solve at that time were to criticize the capitalist society, reveal the law of the development of the capitalist society, and explore the issue of the liberation of the proletariat by the union of the proletariat all over the world to emancipate all mankind through the Communist revolution. Therefore, in essence, Marx doctrine is to pursue the liberation of "people" and realize the free and all-round development of human beings. The humanistic thought of Confucianism serves feudal rule, and Marx's humanistic thought transcends the feudal and capitalist social stages, and stands in the time of the development of human history to think about the subject of human beings. It is a humanitarianism. This is also the height of the traditional Chinese culture, which is not related to humanism. The two cannot be mentioned in the same breath.

In Chinese traditional culture, when each school is creating its own ideological system, most of them want to describe an ideal blueprint of society and life as the goal of the pursuit of human struggle. Confucian "Great Harmony Society" is a typical representative of this thought. The pursuit of the ideal society in Chinese traditional culture embodies the strong dissatisfaction of the Chinese ancient people to the feudal society of human exploitation and the desire for the elimination of the future civilized society of the phenomenon of exploitation and oppression and human service. Marx, however, regarded the liberation of all human beings as their historical mission, advocated overthrowing the rule of capitalism based on private ownership, through the continuous development of productive forces and the improvement of production relations, the final realization of the free and comprehensive development of human beings, and the establishment of a "union of free men" - Communist society. For the pursuit of ideal society, Chinese traditional culture and Marx doctrine are interlinked, but we should see that the pursuit of the ideal society in Chinese traditional culture is based on the self-sufficiency of the small farmers' economy, with a strong sense of imagination, and the pursuit of the ideal society by Marx is a history. On the basis of the high development of the productive forces, the materialism of materialism is based on the high development of the productive forces. Therefore, Marx's pursuit of the ideal society is scientific, which is a place that is not involved in the traditional Chinese culture.

\section{The negative effect of the dregs of traditional culture on the Sinicization of Marx doctrine}

\subsection{Patriarchal hierarchy}

Although the patriarchal system in the strict sense has begun to collapse in the late Western Zhou Dynasty, the influence of the patriarchal clan system on the Chinese nation is all-around and lasting. It has become an important part of the national tradition and social psychology. The requirement of the patriarchal concept, Father's love for his children, Children are filial to their parents, Brotherhood before love, Younger siblings are respectful to their brother. Must obey the requirements of lower nobility, not chaos. Otherwise, "no filial piety and unfriendliness", must be severely punished, can not be pardon. On the one hand, the Chinese nation has a strong national consciousness on the one hand, self-cultivating, family-regulating, state-ordering, then the land great governed, "Every man has a share of responsibility for the fate of his country"; On the other hand, there are also many patriotism and loyalty is not divided, family-regulating and respect one subserviency fathers filial consciousness. After the founding of new China, influenced by patriarchal hierarchy, some of the party members took personal interests above the collective interest, seriously undermining the events of democracy and legality, and made Marx's Sinicization process suffer a major setback.

In Chinese traditional culture, when each school is creating its own ideological system, most of them want to describe an ideal blueprint of society and life as the goal of the pursuit of human struggle. Confucian "Great Harmony Society" is a typical representative of this thought. The pursuit of the ideal society in Chinese traditional culture embodies the strong dissatisfaction of the Chinese ancient people to the feudal society of human exploitation and the desire for the elimination of the future civilized society of the phenomenon of exploitation and oppression and human service. Marx, 
however, regarded the liberation of all human beings as their historical mission, advocated overthrowing the rule of capitalism based on private ownership, through the continuous development of productive forces and the improvement of production relations, the final realization of the free and comprehensive development of human beings, and the establishment of a "union of free men" - Communist society. For the pursuit of ideal society, Chinese traditional culture and Marx doctrine are interlinked, but we should see that the pursuit of the ideal society in Chinese traditional culture is based on the self-sufficiency of the small farmers' economy, with a strong sense of imagination, and the pursuit of the ideal society by Marx is a history. On the basis of the high development of the productive forces, the materialism of materialism is based on the high development of the productive forces. Therefore, Marx's pursuit of the ideal society is scientific, which is a place that is not involved in the traditional Chinese culture.

\subsection{Bureaucratic way of doing things}

Feudal bureaucratic culture, has made China's feudal society stagnate for a long time, and also hindered the process of Marx's Sinicization. Derived from the feudal bureaucratic system of bureaucracy, let the position and social status has become an inevitable contact, even become a measure of a person's status and value scale and standard. Bureaucratism is a long-term and complex historical phenomenon, and it is also a big problem in the political life of the socialist country. The bureaucratic point of view deviates from the mass viewpoint of Marx's doctrine. Therefore, the development of Marx doctrine must be deeply analyzed, criticized and thoroughly eradicated, so as to enhance the subjective position and subjective consciousness of the masses in the process of organic integration of Marx doctrine and excellent traditional culture. Therefore, to the development of the Marx doctrine must carry out in-depth analysis and critique and eradication of bureaucracy, the organic integration of the Marx doctrine and the Marx doctrine to the excellent traditional culture Chinese in the process to strengthen the people's subjectivity and subject consciousness. We must fight against bureaucracy and truly realize that the right is for the people, and that the emotion is for the people, and the interests for the people are Marx.

\subsection{Small peasant economy and culture}

Ancient China was a self-sufficient farming economy based on small farmers. Thousands of years of farming civilization cultivated the Chinese people's economic and cultural mentality of small farmers, which is the material force of the whole Chinese traditional culture. Chinese farmers since ancient times are spring farming, summer cultivation, autumn harvest, winter collection. Chinese has accumulated rich experience in agricultural production and science and technology, thus the formation of the Chinese nation "actual light fantasy", has not paid much attention to pure science fantasy and logical thinking of national character, and the basic characteristics of the traditional culture Chinese pragmatic rationality. The economic and cultural mentality of the small peasant shows dogmatism in the course of the Sinicization of Marx's doctrine. A typical example is the confinement of "two whatever" to people's thought. The "two whatever" deviated from the ideological line of seeking truth from facts and violated the basic principles of Marx's doctrine. Therefore, if not through the "two whatever", the cause of Marx's China would not be possible to get further development, China reform and opening up and socialist modernization practice will can't do anything. From a cultural perspective, the spread of Marx doctrine in China and Its Sinicization process is to overcome the process of "annotating" Marx doctrine with the mindset of small peasant economy and culture.

\section{The dialectical unity of the Sinicization of Marx's doctrine and the traditional Chinese culture}

Any culture has its two sides, so for China traditional culture, we cannot accept the criticism of the traditional culture of no, but should adopt both inheritance and critical attitude, its essence, to its dregs, we must see the positive factors of traditional culture to promote the Marx doctrine of China, but also see that traditional culture is not conducive to the negative factors of Marx's Chinese, 
excellent absorption of the essence of traditional culture, we must be alert to the negative factors into. Only by doing this can we give full play to the role of Chinese traditional culture in the course of the Sinicization of Marx doctrine and promote the Sinicization of Marx doctrine. The Sinicization of Marx is not only to uphold and develop Marx doctrine in theory, and is in the Marx doctrine under the guidance of the socialist and Communist Road, realize modernization in politics, economy, ideology, military, etc. in the field of international relations, so as to completely change the actual Chinese traditional culture of the old. And realize cultural leap overall transformation, create a modern new culture based on the culture of the old abandoned. Marx's Chinese and China interaction and integration of traditional culture, not on the Marx doctrine mechanically, nor is the traditional culture of the Renaissance at Chinese. Marx doctrine and traditional Chinese culture will continue to co influence and develop together. The Sinicization of Marx and Chinese traditional culture will continue to interact and merge. In the process of Marx's sinicization, we must constantly absorb excellent cultural experience and cultural value from traditional culture, and also use the critical spirit of Marx's philosophy to resist the dross in traditional culture. Only in this way can Marx doctrine be closer to the reality of Chinese society, accord with the specific conditions of China, and Push the history wheel of Chinese society forward to the ideal goal of communism.

\section{References}

[1] Mingbo Zhang. The Development and Evolution of Marxist Sociology since the Reconstruction of Chinese Sociology[A]. 2017:5.

[2] Liu Ye. Study on the Process of Public Administration Ethics Education Based on Complexity Theory[A]. 2014:5.

[3] Qiulan Chen. Analysis of Deepening Strategies on Sinicization of Marxism[A]. 2012:5.

[4] Hong Zhang Ideological and Political Theory Teaching and Research Department, Shenyang University, Shenyang, China. Analysis on the Choice of Guiding Ideology and Innovative Methods in China's Modernization Course[A]. 2011:3. 